\title{
PENINGKATAN KEMAMPUAN KOGNITIF ANAK USIA DINI MELALUI MEDIA KARTU ANGKA
}

\author{
Febriyanti Utami \\ Dosen FKIP Universitas PGRI Palembang
}

\begin{abstract}
ABSTRAK
Penelitian ini bertujuan untuk meningkatkan kemampuan kognitif anak dalam mengenal lambang bilangan melalui media kartu angka pada anak Kelompok A Kelompok Bermain PAUD Taman Sari I. Penelitian ini merupakan penelitian tindakan kelas dengan subjek penelitian anak Kelompok A sebanyak 15 anak yang terdiri dari 10 anak perempuan dan 5 anak laki-laki. Penelitian ini terdiri dari 2 siklus dengan masing-masing tahapan yaitu perencanaan, pelaksanaan, pengamatan dan refleksi. Teknik pengumpulan data yang digunakan dalam penelitian ini adalah observasi yang berupa lembar pengamatan kemampuan kognitif anak dalam mengenal lambang bilangan dan dokumentasi. Berdasarkan hasil penelitian yang dilakukan, kemampuan kognitif anak dalam mengenal lambang bilangan dapat meningkat dengan menggunakan media kartu angka. Hal ini ditunjukkan dengan meningkatnya rata-rata persentase kemampuan kognitif anak dalam mengenal lambang bilangan pada tahap pra siklus yaitu $26.7 \%$ menjadi $57.7 \%$ pada siklus I dan $86.7 \%$ pada siklus II setelah dilakukannya tindakan dengan menggunakan media kartu angka dalam proses pembelajaran. Dengan demikian dapat disimpulkan bahwa penggunaan media kartu angka dapat meningkatkan kemampuan kognitif anak dalam mengenal lambang bilangan pada Kelompok A Kelompok Bermain Taman Sari I.
\end{abstract}

Kata Kunci:Kemampuan Kognitif, Lambang Bilangan, Kartu Angka

\section{A.PENDAHULUAN}

Anak usia dini merupakan individu yang berbeda, unik, dan memiliki karakteristik tersendiri sesuai dengan tahapan usianya. Masa usia dini merupakan masa keemasan di mana stimulasi seluruh aspek perkembangan berperan penting untuk tugas perkembangan selanjutnya.

Salah satu aspek perkembangan yang perlu distimulasi pada usia dini adalah kemampuan kogitif. Kemampuan kognitif adalah suatu proses berpikir, untuk menciptakan daya cipta, kemampuan untuk menghubungkan, menilai, dan mempertimbangkan sesuatu. Pengembangan kemampuan kognitif bertujuan untuk meningkatkan kemampuan berpikir anak dalam rangka membekali anak untuk di kehidupan di masa depan.

Salah satu aspek kognitif yang harus dikembangkan yaitu kemampuan matematika dasar berupa mengenal lambang bilangan. Pembelajaran matematika dasar sudah dapat diajarkan pada anak usia dini dengan penggunaan strategi, metode serta media yang digunakan dalam penyampaiannya tetap disesuaikan 
dengan tingkat usia dan perkembangan anak usia dini.

Berdasarkan temuan di lapangan pada kelompok A di KB Taman Sari I terlihat bahwa kemampuan mengenal lambang bilangan anak masih tergolong rendah. Anak mengenal lambang bilangan sebatas hafalan, sehingga anak masih terbolak-balik ketika diminta menyebutkan lambang bilangan yang ditunjukkan oleh guru. Kondisi ini diduga, dalam proses pembelajaran guru belum sepenuhnya menggunakan media pembelajaran. Proses pembelajaran yang selama ini dipakai masih berpusat pada guru.

Untuk mengatasi permasalahan tersebut, salah satu alternatif yang digunakan yaitu dengan memanfaatkan media pembelajaran. Melalui pemanfaatan media pembelajaran yang dalam penelitian ini digunakan media pembelajaran kartu angka, diharapkan anak akan lebih tertarik dan senang dalam mengikuti proses pembelajaran. Selain itu pembelajaran akan lebih mengena dan mudah dipahami oleh anak.

Berdasarkan uraian di atas peneliti tertarik untuk menindaklanjuti permasalahan tersebut dengan melakukan penelitian dengan judul Peningkatan Kemampuan Kognitif Anak Usia Dini Dengan Menggunakan Media Kartu Angka Pada Kelompok A di KB Taman Sari I.

Kemampuan Kognitif adalah kemampuan tentang pengatahuan (Suhadad, 2016:19). Susanto (2012: 48) bahwa kognitif adalah suatu proses berpikir,yaitu kemampuan individu untuk menghubungkan, menilai, dan mempertimbangkan suatu kejadian atau peristiwa. Hal ini sejalan dengan pendapat Gagne (dalam Darsinah: 2011) bahwa kognitif adalah proses yang terjadi secara internal di dalam susunan syaraf pada waktu manusia sedang berfikir.

Cavanagh dalam Agustin dan Muslihuddin (2008:11) mengungkapkan bahwa kognitif merupakan bagian intelegensi yang merujuk pada penerimaan, penafsiran pemikiran, pengingatan, pengkhayalan, pengambilan keputusan dan penalaran hingga mampu memberikan respon terhadap kejadian yang terjadi secara internal maupun eksternal. Dapat disimpulkan, kemampuan kognitif adalah proses dari berfikir dalam hal menghubungkan, menilai, dan mempertimbangkan suatu kejadian atauperistiwa yang dialami oleh seseorang.

Kemampuan kognitif dalam penelitian ini dibatasi pada lingkup perkembangan berfikir logis dalam mengenal lambang bilangan. Lambang bilangan adalah simbol atau lambang yang digunakan untuk pemecahan dan penngukuran, simbol atau lambang yang digunakan untuk mewakili suatu bilangan atau angka (Anderson, 2010: 7).

Hajid (2015:7) menyatakan bahwa lambang bilangan merupakan konsep matematika yang digunakan untuk pencacahan dan pengukuran, simbol atau lambang yang digunakan untuk mewakili suatu bilangan. Dalam penelitian ini kemampuan mengenal lambang bilangan yang akan ditingkatkan yaitu kemampuan dalam mengurutkan lambang bilangan $1-10$, menunjukklan lambang bilangan $1-10$, dan menghubungkan lambang bilangan dengan benda dari $1-10$.

Peningkatan kemampuan kognitif dalam mengenal lambang bilangan dalam penelitian ini dilakukan dengan 
menggunakan media pembelajaran. Gagne dan Briggs dalam Sardiman, dkk. (2006:6) berpendapat bahwa media adalah berbagai jenis komponen dalam lingkungan anak yang dapat merangsangnya untuk belajar.

Media pembelajaran yang digunakan dalam pengenalan lambang bilangan pada penelitian yang dilakukan yaitu media kartu angka.Bruner (Suherman, 2001 : 44) kartu angka merupakan alat permainan manipulatif yang di dalamnya termuat gambar replika suatu benda yang ada di sekitar anak. Angka merupakan simbol atau lambang suatu bilangan, dimana pada usia TK anak sudah mulai mengenal symbol dan gambar.

Kartu angka adalah alat-alat atau perlengkapan yang digunakan oleh seorang guru dalam mengajar yang berupa kartu bertuliskan angka sesuai dengan tema yang diajarkan (Sujiono, 2012). Chaloux

(2017) mengungkapkan bahwa "preschoolers who are learning to count and recognize numbers can use card games to sequence the numbers found on the cards". Yang diartikan bahwa anak usia prasekolah belajar menghitung dan mengenali angka dapat menggunakan permainan kartu untuk mengurutkan angka yang terdapat pada kartu.

Curran dalam Saputra dan Rudiyanto (2005: 69) mengemukakan bahwa keunggulan mengenal lambang bilangn melalui penggunaan media kartu angka adalah : 1) anak mencari kartu sesuai pasangannya sambil belajar mengenali konsep dalam suasana yang menyenangkan; 2) anak mengenali konsep komunikasi dengan kalimat sederhana; 3) anak mengenali konsep bilangan dengan benda-benda serta menghubungkan konsep bilangan dengan lambang bilangan.

\section{B.METODE}

Penelitian ini dilakukan dengan menggunakan metode penelitian tindakan kelas (PTK). Desain penelitian yang digunakan pada penelitian tindakan kelas ini menggunakan desain yang dikemukakan oleh Kemmis \& Mc. Taggart (dalam Arikunto, 2013:137). Desain yang digunakan terdiri dari empat tahap, yaitu: perencanaan, pelaksanaan, pengamatan dan refleksi.

Tempat penelitian ini dilakukan di Kelompok Bermain Taman Sari Jl. Pangeran Ayin Komp. Taman Sari I Blok J.9 - L.6 Kel. Kenten Kec. Talang Kelapa Kab. Banyuasin. Waktu penelitian ini dilaksnakan pada semester genap tahun akademik 2016/2017 dimulai dari bulan Juli Agustus 2017.

Subjek penelitian ini adalah anak pada Kelompok A Kelompok Bermain Taman Sari I yang berusia 4 - 5 tahun yang berjumlah 15 anak. Terdiri dari 10 anak perempuan dan 5 anak laki-laki.

Teknik pengumpulan data yang dilakukan dalam penelitian ini adalah pengamatan dan dokumentasi. Data yang dikumpulkan melalui lembar observasi berupa data kemampuan kognitif anak dalam mengenal lambang bilangan dengan menggunakan media kartu angka. Observasi digunakan untuk mengetahui tingkat keberhasilan maupun kelemahan selama proses kegiatan berlangsung. Sedangkan dokumentasi digunakan untuk memberikan gambaran nyata mengenai kegiatan yang telah dilakukan guru dan siswa pada saat proses pembelajaran berlangsung 
untuk memperkuat data yang diperoleh dalam penelitian ini.

Penelitian ini akan dikatakan berhasil apabila kemampuan kognitif anak dalam mengenal lambang bilangan telah mengalami peningkatan sebesar $80 \%$ atau dengan kriteria baik.

\section{C.HASIL DAN PEMBAHASAN}

Pada tahap pra siklus, kegiatan pembelajaran dalam mengenal lambang bilangan anak hanya sebatas penggunaan lembar kerja anak. Dari proses pelaksanaan pembelajaran pengenalan lambang bilangan pada tahap pra siklus diperoleh data observasi sebagai berikut:

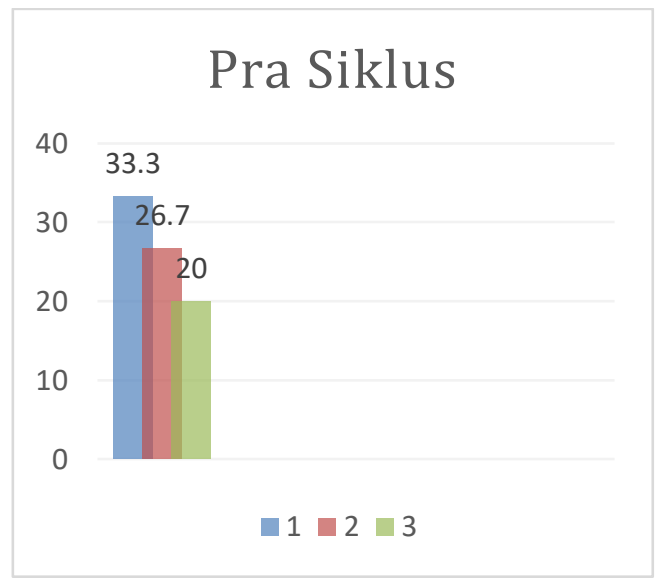

Gambar 1. Data kemampuan kognitif dalam mengenal lambang bilangan pada tahap pra siklus.

Keterangan:

$1=$ Anak dapat menyebutkan lambang bilangan $1-10$

$2=$ Anak dapat mengurutkan lambang bilangan $1-10$

3 = Anak dapat menghubungkan lambang bilangan dengan jumlah benda

Berdasarkan gambar di atas dapat dijelaskan bahwa kemampuan mengenal lambang bilangan anak pada Kelompok A di Kelompok Bermain Taman Sari I masih banyak anak yang belum mampu mengenal lambang bilangan dengan baik.

Hasil pengamatan pada indikator 1 hanya terdapat 5 anak yang mampu menyebutkan lambang bilangan 1-10 atau sama dengan $33.3 \%$. Pada indikator 2 hanya terdapat 4 anak yang mampu anak yang mampu mengurutkan lambang bilangan 1 10 atau sama dengan $26.7 \%$. Pada indikator 3 hanya terdapat 2 anak yang mampu menghubungkan lambang bilangan dengan jumlah benda atau sama dengan $20 \%$. Ratarata kemampuan kognitif dalam mengenal lambang bilangan yaitu $26.7 \%$, masih berada di bawah kriteria keberhasilan tindakan yang ditetapkan. Maka dari itu peneliti berusaha untuk meningkatkan kemapuan kognitif dalam mengenal lambang bilangan dengan menggunakan media kartu angka.

Hasil penelitian pada siklus I, anak sudah menunjukkan ketertarikan dalam kegiatan pembelajaran menggunakan media kartu angka yang dirancang oleh peneliti. Berikut ditampilkan hasil dari rekapitulasi data kemampuan mengenal lambang bilangan menggunakan media kartu angka :

\section{Siklus I}

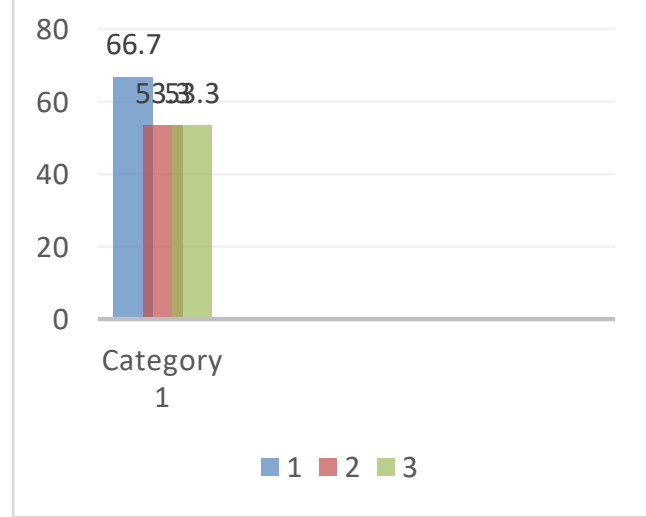


Gambar 2. Data kemampuan mengenal lambang bilangan pada siklus I.

Keterangan:

$1=$ Anak dapat menyebutkan lambang bilangan $1-10$

$2=$ Anak dapat mengurutkan lambang bilangan $1-10$

3 = Anak dapat menghubungkan lambang bilangan dengan jumlah benda

Hasil pengamatan siklus I pada indikator 1 terdapat 10 anak yang mampu menyebutkan lambang bilangan 1 - 10 atau sama dengan $66.7 \%$. Pada indikator 2 terdapat 8 anak yang mampu anak yang mampu mengurutkan lambang bilangan 1 10 atau sama dengan $53.3 \%$. Pada indikator 3 terdapat 8 anak yang mampu menghubungkan lambang bilangan dengan jumlah benda atau sama dengan $53.3 \%$. Rata-rata kemampuan kognitif dalam mengenal lambang bilangan pada siklus I meningkat menjadi $57.7 \%$.

Berdasarkan data tersebut dapat dilihat bahwa kemampuan kognitif anak dalam hal mengenal lambang bilangan mengalami peningkatan, tetapi masih belum mencapai indikator keberhasilan yang ditetapkan oleh peneliti sebesar $80 \%$. Untuk itu peneliti masih perlu melakukan perbaikan pada proses pembelajaran dengan melanjutkannya pada siklus II.

Hasil rekapitulasi data kemampuan kognitif anak dalam mengenal lambang bilangan pada siklus II dapat dilihat pada gambar di bawah ini :

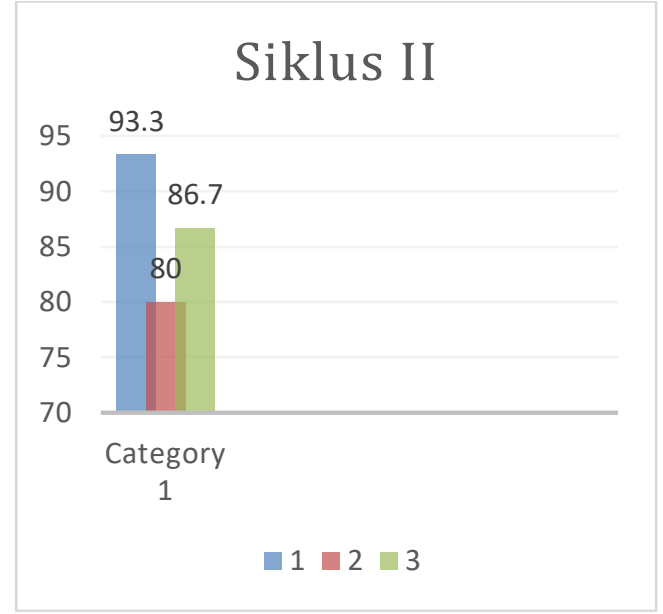

Gambar 3. Data kemampuan kognitif mengenal lambang bilangan pada siklus II.

Keterangan:

$1=$ Anak dapat menyebutkan lambang bilangan $1-10$

$2=$ Anak dapat mengurutkan lambang bilangan $1-10$

3 = Anak dapat menghubungkan lambang bilangan dengan benda 1 10

Hasil pengamatan pada indikator 1 terdapat 14 anak yang mampu menyebutkan lambang bilangan $1-10$ atau sama dengan $93.3 \%$. Pada indikator 2 terdapat 12 anak yang mampu anak yang mampu mengurutkan lambang bilangan 1 10 atau sama dengan $80 \%$. Pada indikator 3 terdapat 13 anak yang mampu menghubungkan lambang bilangan dengan jumlah benda atau sama dengan $86.7 \%$. Rata-rata kemampuan kognitif dalam mengenal lambang bilangan pada siklus II yaitu $86.7 \%$.

Pada Siklus II ini kemampuan kognitif anak telah mencapai indikator keberhasilan yang telah ditentukan oleh peneliti. Untuk itu peneliti menghentikan tindakan sampai pada siklus II. 


\section{Pembahasan}

Berdasarkan pemerolehan data secara kualitatif dan kuantitatif, penelitian ini telah membuktikan bahwa media kartu angka dapat meningkatkan kemampuan kognitif anak dalam mengenal lambang bilangan.Kemampuan kognitif anak dalam mengenal lambang bilangan sangat penting dikuasai oleh anak. Kemampuan kognitif anak dalam mengenal lambang bilangan ditunjukkan oleh anak selama diberi tindakan penelitian dilihat dari beberapa indikator antara lain menyebutkan lambang bilangan 1 10 , mengurutkan lambang bilangan 1 - 10, dan menghubungkan lambang bilangan dengan jumlah benda $1-10$.

Berdasarkan hasil yang diperoleh pada tahap pra siklus kemampuan kognitif anak dalam mengenal lambang bilangan masih terlihat rendah. Hal ini diebabkan pembelajaran mengenal lambang bilangan hanya menggukan lembar kegiatan anak. Masih terbatas dan kurang bervariasinya dalam penggunaan media pembelajaran dalam proses pembelajaran. Sehingga proses pembelajaran membuat anak menajdi bosan dan kurang fokus. Berpijak pada permasalahan yang muncul, perlu ditingkatkannya kemampuan kognitif dalam hal mengenal lambang bilangan pada anak. Oleh karena itu, diperlukan kegiatan yang menyenangkan dan dapat menarik minat anak dalam proses pembelajaran.

Berdasarkan hasil penelitian yang telah dilakukan, menunjukkan bahwa media kartu angka dapat meningkatkan kemampuan kognitif anak dalam mengenal lambang bilangan. Peningkatan tersebut dapat terlihat dari adanya peningkatan persentase pada tahap pra siklus dan setelah dilakukannya tindakan pada sikuis I dan siklus II.

Pada tahap pra siklus terlihat bahwa kemampuan kognitif anak dalam mengenal lambang bilangan masih berada di bawah kriteria keberhasilan. Setelah adanya tindakan yang dilakukan pada siklus I, kemampuan kognitif anak mulai meningkat, tetapi masih berada dibawah kriteria keberhasilan. Setelah dilakukan perbaikan dengan melihat hasil tindakan siklus I, pada siklus II rata-rata kemampuan kognitif anak dalam mengenal lambang bilangan meningkat menjadi $86.7 \%$ dan memenuhi kriteria keberhasilan tindakan yang telah ditetapkan oleh peneliti.

Berdasarkan hasil penelitian pada siklus I terlihat anak sudah tertarik dengan proses pembelajaran yang dilakukan. Proses pembelajaran yang dilakukan sudah menggunakan media kartu angka, yang dapat merangsang anak untuk terlibat aktif dalam proses pembelajaran. Pada prinsipnya pembelajaran pada anak usia dini tidak terlepas dari kegaiatan yang menyenangkan. Namun, dalam pelaksanaan tindakan pada siklus I kegiatan masih kurang kondusif dan anak masih belum fokus dalam mengikuti proses pembelajaran. Kekurangan ini disebabkan media pembelajaran kartu angka yang digunakan masih sederhana. Untuk itu peneliti memperbaiki media kartu angka dengan menambahkan gambar benda-benda menarik yang disesuaikan dengan jumlah angka pada kartu angka tersebut.

Pada siklus II anak semakin antusias, terlibat aktif dan lebih fokus dalam mengikuti proses pembelajaran. Sehingga kemampuan kognitif anak dalam mengenal lambang bilangan dapat meningkat. Hal ini sesuai 
dengan pendapat yang dikemukakan oleh Saputra dan Rudiyanto (2005:69) yang menyatakan bahwa kegiatan pembelajaran melalui penggunaan media kartu angka merupakan cara yang tepat untuk membantu anak dalam meningkatkan kemampuan mengenal lambang bilangan, karena media ini menggunakan benda-benda yang ada disekitar anak, warna yang digunakan menarik serta penggunaan kartu yang bersifat fleksibel. Dapat digunakan secara individu dan berkelompok.

\section{D.KESIMPULAN}

Berdasarkan hasil penelitian dan pembahasan dapat ditarik simpulan bahwa: 1) kemampuan kognitif anak dalam mengenal lambang bilangan pada Kelompok A Kelompok Bermain Taman Sari I Kenten Laut dapat ditingkatkan dengan menggunakan media kartu angka; 2) adanya peningkatan persentase ratarata dari tahap pra siklus dan setelah dilakukannya tindakan pada siklus I dan II; 3) hasil observasi menunjukkan bahwa setelah diadakannya tindakan pada siklus II dengan menggunakan media kartu angka, kemampuan kognitif anak dalam mengenal lambang bilangan yang berkriteria baik meningkat.

Berdasarkan hasil penelitian yang dilaksanakn, saran yang dapat diberikan penulis antara lain: 1) bagi guru, guru dapat menggunakan media kartu angka sebagai alternatif dalam proses pembelajaran untuk meningkatkan kemampuan kognitif dalam mengenal lambang bilangan pada anak usia dini, terutama pada Kelompok A program Kelompok Bermain, 2) bagi sekolah, memebrikan dan menyediakan fasilitas yang mendukung proses pembelajaran dengan menggunakan media pembelajaran yang menarik, mendukung upaya guru dalam menggunakan media pembelajaran kartu angka untuk meningkatkan kemampuan kognitif anak dalam mengenal lambang bilangan.

\section{REFERENSI}

Agustin, Mubiar dan Muslihuddin. 2008. Mengenali dan Mengembangkan Potensi Kecerdasan Jamak Anak Usia Taman Kanak-Kanak / Raudhatuf Athfal. Bandung: Rizqi Press.

Anderson, S. 2010. Buku Memori Matematika SD Untuk Kelas 4, $5 \quad \& \quad 6 . \quad$ Jakarta: PT Wahyumedia.

Arikunto, Suharsimi. 2013. Prosedur Penelitian Suatu Pendekatan Praktik. Jakarta: Rineka Cipta.

Chaloux, Stacey. 2017. Games for Cognitive Development During Early Childhood. (https://www.livestrong.com/art icle/1000692-games-cognitivedevelopment-during-earlychildhood/, diakses pada tanggal 24 September 2017)

Darsinah. 2011. Perkembangan Kognitif. Surakarta: Universitas Muhammadiyah Surakarta.

Hajid, M. 2015. Buku Master SMP/MTs 5 in 1. Jakarta: Media Pusindo.

Saputra, Yudha M. dan Rudiyanto. 2005. Pembelajaran Kooperatif Untuk Meningkatkan Keterampilan Anak TK. Jakarta: Depdiknas Dirjen Pendidikan Tinggi Direktorat Pembinaan Pendidikan

Tenaga Kependidikan dan Ketenagaan Pendidikan Tinggi.

Sardiman, Arif S., dkk. 2006. Media PendidikanI. Jakarta: Rineka Cipta. 
Suhadad, Idad. 2016. Psikologi Perkembangan Anak Usia Dini (Raudhatul Athfal). Bandung: PT Remaja Rosdakarya.

Suherman, Erman, dkk. 2001. Strategi Pembelajaran Matematika Kontemporer. Bandung: JICA

Sujiono, Yuliani Nurani. 2012. Bermain Kreatif Berbasis Kecerdasan Jamak. Jakarta: PT Indeks.

Susanto, 2012. Perkembangan Anak Usia Dini. Jakarta: Kencana Prenada Media Group. 